\title{
KOMPARASI KINERJA ALGORITMA C4.5, GRADIENT BOOSTING TREES, RANDOM FORESTS, DAN DEEP LEARNING PADA KASUS EDUCATIONAL DATA MINING
}

\author{
Siti Mutrofin *1, M. Mughniy Machfud ${ }^{2}$, Diema Hernyka Satyareni ${ }^{3}$, Raden Venantius Hari Ginardi ${ }^{4}$, \\ Chastine Fatichah ${ }^{5}$ \\ ${ }^{1,2,3}$ Sistem Informasi, Universitas Pesantren Tinggi Darul Ulum, ${ }^{4,5}$ Teknik Informatika, Institut Teknologi \\ Sepuluh Nopember \\ Email: ${ }^{1}$ sitimutrofin@ft.unipdu.ac,id, ${ }^{2}$ machfudmughniy03@gmail.com, ${ }^{3}$ diemahernyka@ @t.unipdu.ac.id, ${ }^{4}$ \\ hari.ginardi@gmail.com, 5 chastine@if.its.ac.id \\ *Penulis Korespondensi
}

(Naskah masuk: 4 November 2019, diterima untuk diterbitkan: 25 November 2019)

\begin{abstract}
Abstrak
Penentuan jurusan di SMA Negeri 1 Jogoroto, Jombang, Jawa Timur menggunakan kurikulum 2013, di mana penentuan jurusan siswa tidak hanya melibatkan keinginan siswa, tes peminatan yang dilakukan siswa di SMA pada minggu pertama, tetapi juga dilengkapi dengan nilai siswa semasa di SMP (nilai rapor siswa, nilai Ujian Nasional, serta rekomendasi guru Bimbingan Konseling), rekomendasi orang tua siswa. Selama ini, sekolah menggunakan proses konvensional dalam menentukan jurusan, yaitu menggunakan Microsoft Excel, yang cenderung lama serta rawan akan kekeliruan dalam melakukan penghitungan. Penentuan jurusan ini dilakukan setiap awal ajaran baru pada siswa baru kelas X. Rata-rata setiap tahun, sekolah mengelola siswa sejumlah 290 dengan waktu dan sumber daya manusia yang terbatas. Pada penelitian ini, penggunaan algoritma ID3 tidak cocok karena data bertipe numerik, sedangkan ID3 hanya mampu menggunakan data bertipe nomial maupun polinomial, sehingga diganti algoritma C4.5. Namun, beberapa penelitian mengatakan algoritma C4.5 memiliki kinerja kurang bagus dibandingkan algoritma Gradient Boosting Trees, Random Forests, dan Deep Learning. Untuk itu, dilakukan perbandingan antara keempat metode tersebut untuk melihat keefektifannya dalam menentukan jurusan di SMA. Data yang digunakan pada penelitian ini adalah data penerimaan siswa baru tahun ajaran 2018/2019. Hasil dari penelitian ini menunjukkan jika atribut yang digunakan bertipe polinomial dengan Deep Learning memiliki kinerja paling unggul untuk semua algoritma jika menggunakan fungsi activation ExpRectifier. Sedangkan jika atributnya bertipe numerik, Deep Learning memiliki kinerja paling unggul untuk semua algoritma jika menggunakan fungsi Tanh untuk semua random sampling. Namun, Deep Learning memiliki kinerja paling buruk untuk semua algoritma jika menggunakan loss Function berupa absolut.
\end{abstract}

Kata kunci: C4.5, deep learning, gradient boosting trees, penentuan jurusan, random forest, SMA

\section{PERFORMANCE COMPARISON BETWEEN ALGORITHMS OF C4.5, GRADIENT BOOSTING TREES, RANDOM FORESTS, AND DEEP LEARNING IN EDUCATIONAL DATA MINING}

\begin{abstract}
In SMAN 1 Jombang, East Java, the process of determining the students' majors referred to the 2013 curriculum in which not only the students' own choices and specialization tests conducted in their first week of SMA were considered but also the student's SMP grades (a report card, UN scores, and counseling teacher's recommendation) and parents' recommendation. So far, the school had used Microsoft Excel which required a long time to do and was prone to calculation errors in the process of determination. The process was carried out, with limited time and human resources, at the beginning of a new academic year for grade $X$ students, consisting of 290 students on average. In this present research, the use of ID3 algorithm was not suitable because of its numeric data type instead of nominal or polynomial data. Thus, the C4.5 algorithm was applied, instead. However, the performance of C4.5 algorithm was proved lower than the algorithms of Gradient Boosting Trees, Random Forests, and Deep Learning. Hence, a comparison of performance between them was done to see their effectiveness in the process. The data was the list of new students of the academic year 2018/2019. The results showed that if the attributes are polynomial, the Deep Learning algorithm had the best
\end{abstract}


performance when using the ExpRectifier activation function. When they were numeric, Deep Learning has the most superior performance when using the Tanh function. However, Deep Learning has the worst performance when using the loss function in the form of absolute.

Keywords: C4.5, deep learning, determining majors, gradient boosting trees, high school, random forest.

\section{PENDAHULUAN}

Penentuan jurusan di tingkat Sekolah Menengah Atas (SMA) Negeri 1 Jogoroto, Jombang, Jawa Timur saat ini berbasis Kurikulum 2013 (K13), yang mana pada kurikulum ini penentuan jurusan tidak hanya melibatkan keinginan siswa dan tes peminatan, tetapi juga dilengkapi dengan nilai rapor siswa selama masa pendidikan di tingkat Sekolah Menengah Pertama (SMP), nilai Ujian Nasional (UN), rekomendasi orang tua, serta rekomendasi guru Bimbingan Konseling (BK) samasa pendidikan di SMP.

Selama ini proses untuk menentukan jurusan masih bersifat konvensional menggunakan Microsoft Excel, yang mana penentuan seperti ini rawan akan kekeliruan dalam melakukan penghitungan, jika tidak benar-benar berhati-hati dan membutuhkan waktu yang lama. Sedangkan penentuan jurusan ini dilakukan setiap awal ajaran baru pada siswa baru kelas $\mathrm{X}$, rata-rata setiap tahun mengelola siswa sejumlah 289 dengan waktu dan sumber daya manusia (SDM) yang terbatas.

Permasalahan ini telah menjadi perhatian banyak pelitian, diantaranya menerapkan Educational Data Mining (Peña-Ayala, 2014; Khan \& Ghosh, 2018; Márquez- Vera, et al., 2016; Natek \& Zwilling, 2014; Márquez-Vera, et al., 2013) berbasis klasifikasi untuk kasus yang sama yaitu penentuan jurusan di tingkat SMA dengan menggunakan algoritma kombinasi antara algoritma kNN dan SMART (Kustiyahningsih \& Syafa'ah, 2015), ada pula yang menggunakan algoritma ID3 (Kristanto, 2014). Namun, tidak semua data cocok menggunakan algoritma tersebut dari sisi karakteristik atribut datanya. Pada penelitian ini data yang digunakan tidak cocok jika menggunakan algoritma ID3 karena data memiliki karakteristik tipe data berupa numerik, sedangkan pada ID3 hanya mampu menggunakan data bertipe nominal maupun polinomial, sebagai penggantinya adalah algoritma yang bisa digunakan adalah C4.5 (Mutrofin, et al., 2019). Namun, beberapa penelitian menyatakan algoritma C4.5 masih memiliki kinerja kurang bagus dibandingkan algoritma Gradient Boosting Trees, Random Forests (Brown \& Mues, 2012), dan Deep Learning (Handhayani, et al., 2018) tetapi untuk kasus lain, bukan penentuan jurusan di SMA, untuk itu pada penelitian ini akan dilakukan perbandingan antara keempat metode tersebut untuk membuktikan pernyataan tersebut pada kasus ini.

\section{METODE PENELITIAN}

Metode penelitian yang diusulkan disajikan pada Gambar 1, adapun penjelasan dari Gambar 1 disajikan pada kalimat berikut ini. Tahapan pertama adalah pengumpulan data. Data yang digunakan pada penelitian ini didapatkan dari SMA Negeri 1 Jogoroto yang di bawah naungan Pemerintahan Kabupaten Jombang, Jawa Timur. Data asli berjumlah 291 siswa dari siswa baru tahun ajaran 2018/2019, karena penetuan jurusan pada Kurikulum 2013 ditetukan di tahun pertama pendidikan SMA. Data terdiri dari siswa yang terpilih pada jurusan IPA (Ilmu Pengetahuan Alam) sejumlah 124 siswa, IPS (Ilmu Pengetahuan Sosial) sejumlah 134 siswa, dan Bahasa sejumlah 33 siswa.

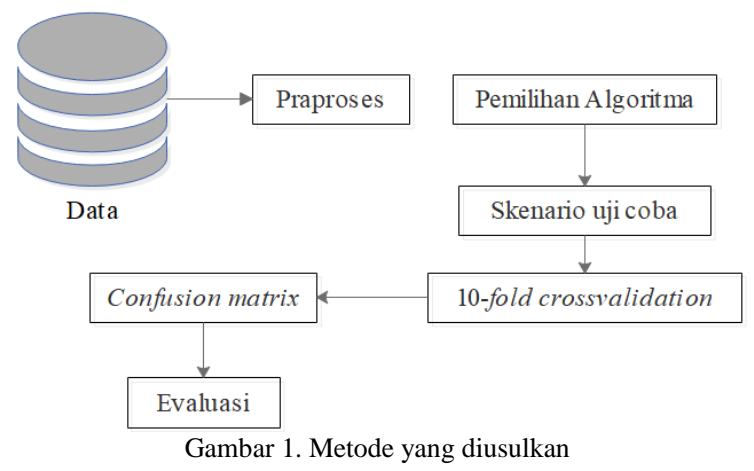

Namun pada siswa yang terpilih pada jurusan IPS dan Bahasa masing-masing ada satu siswa yang datanya terdapat missing value, sehingga dilakukan tahap kedua berupa praproses data, pada tahapan pertama dari praposes dilakukan reduksi data dengan cara menghapus data yang berupa missing value. Oleh karena itu, total data yang digunakan adalah sejumlah 289 yang terdiri dari siswa yang terpilih pada jurusan IPA sejumlah 124 siswa, IPS sejumlah 133 siswa, dan Bahasa sejumlah 32 siswa. Data asli memiliki 15 atribut yang terdiri dari nomor urut, jalur masuk, nama siswa, jenis kelamin siswa, nilai rapor semua rumpun mata pelajara IPA, IPS dan Bahasa selama menempuh pendidikan di jenjang SMP (Sekolah Menengah Pertama) dari kelas VII hingga kelas IX, nilai rapor tertinggi dari 3 rumpun mata pelajaran (IPA, IPS dan Bahasa), nilai Ujian Nasional Matematika dan IPA (UN MIPA), jurusan berdasarkan pilihan siswa, jurusan berdasarkan pilihan orang tua, jurusan berdasarkan pilihan guru Bimbingan Konseling (BK) selama di SMP, nilai peminatan, nilai total (nilai rapor tertinggi, nilai UN MIPA, jurusan pilihan siswa, jurusan berdasarkan 
pilihan orang tua, jurusan berdasarkan pilihan guru BK, dan nilai tes peminatan), dan terakhir nilai yang sudah diperingkatkan menjadi 3 katerogi IPA (nilai total 502,5-385), IPS (nilai total 382,5-290) dan Bahasa (nilai total 288,5-212,5) berdasarkan nilai total. Praproses data yang kedua adalah memilih nilai rapor selama SMP yang tertinggi dari tiga rumpun mata pelajaran. Jika total nilai rapor yang tertinggi adalah rumpun IPA maka diberikan nilai 75 untuk nilai rapor, sedangkan jika tertinggi adalah IPS maka diberi nilai 50, dan jika nilai tertinggi adalah Bahasa maka diberi nilai 25.

Tabel 1. Atribut penentuan rekomendasi jurusan berdasarkan nilai rapor dari kelas X sampai kelas XII selama di SMP

\begin{tabular}{ccccc}
\hline Bahasa & MIPA & IPS & $\begin{array}{c}\text { Nilai } \\
\text { Rapor }\end{array}$ & Keterangan \\
\hline 1006 & $\mathbf{1 0 1 5}$ & 1013 & 75 & IPA \\
969 & $\mathbf{9 7 2}$ & 959 & 75 & IPA \\
986 & 980 & $\mathbf{9 9 0}$ & 50 & IPS \\
1083 & 1058 & $\mathbf{1 1 1 8}$ & 50 & IPS \\
819,7 & $\mathbf{8 2 0 , 9}$ & 812,7 & 75 & IPA \\
\hline
\end{tabular}

Praproses ketiga adalah memilih atribut yang tepat untuk digunakan dalam proses klasifikasi penentuan jurusan pada tingkat Sekolah Menengah Atas (SMA), di mana atribut yang terpilih sejumlah 6 atribut yang terdiri dari nilai rapor tertinggi, nilai UN, pilihan siswa itu sendiri, pilihan orang tua siswa, rekomendasi guru BK, dan hasil tes peminatan di minggu pertama menjadi siswa di SMA Negeri 1 Jogoroto. Data asli sesungguhnya adalah berupa numerik, namun untuk semua nilai atribut kecuali nilai UN hanya terdiri dari 3 jenis, yaitu nilai 75 yang sudah pasti akan direkomendasikan pada jurusan IPA (Ilmu Pengetahuan Alam), 50 yang sudah pasti akan direkomendasikan pada jurusan IPS (Ilmu Pengetahuan Sosial), dan 25 yang sudah pasti akan direkomendasikan pada jurusan Bahasa. Oleh karena itu, pengujian nanti akan melibatkan pengujian ketika nilai atribut selain nilai UN, bertipe numerik juga bertipe polinomial, di mana 75 (IPA), 50 (IPS), dan 25 (Bahasa). Nilai rapor diambil dari nilai kelas $\mathrm{X}$ hingga kelas XII di masa pendidikan SMP, yang terdiri dari rumpun mata pelajaran Bahasa untuk jurusan Bahasa, rumpun mata pelajaran Matematika dan IPA untuk jurusan IPA, dan rumpun mata pelajaran IPS untuk jurusan IPS. Nilai teringgi dari masing-masing 3 mata pelajaran tersebut yang akan terpilih sebagai rekomendasi jurusan berdasarkan nilai rapor. Contoh rekomendasi jurusan berdasarkan nilai rapor disajikan dalam Tabel 1.

Tahap ketiga adalah pemilihan algoritma, diantaranta adalah algoritma dari Decision Tree yang diwakili oleh C4.5 yang sudah terbukti digunakan pada penelitian sejenis dalam penentuan jurusan tetapi di tingkat perguruan tinggi (Swastina, 2013), karena atribut tidak hanya bertipe numerik tetapi juga polinomial. Selain C4.5 juga akan digunakan algoritma Gradient Boosting Trees, Random Forests (Brown \& Mues, 2012) dan Deep
Learning (Handhayani, et al., 2018) karena sudah terbukti kehandalannya di bidang klasifikasi.

Tahap keempat adalah pengujian. Pengujian akan dilakukan menggunakan 2 skenario untuk rekomendasi berdasarkan nilai, yaitu skenario uji coba data bertipe numerik berupa integer karena bilangan bulat, seperti pada Tabel 1 kolom Nilai Rapor dan skenario uji coba 2 bertipe polinomial karena nilai 75 akan dikonversi menjadi IPA, 50 menjadi IPS dan 25 menjadi Bahasa, seperti pada Tabel 1 kolom Keterangan.

Tabel 2. Atribut penentuan rekomendasi jurusan berdasarkan pilihan siswa, orang tua siswa, guru BK, dan tes peminatan

\begin{tabular}{ccccc}
\hline Siswa & $\begin{array}{c}\text { Orang } \\
\text { tua }\end{array}$ & $\begin{array}{c}\text { Guru } \\
\text { BK }\end{array}$ & $\begin{array}{c}\text { Tes } \\
\text { Peminatan }\end{array}$ & Keterangan \\
\hline 75 & 75 & 75 & 75 & IPA \\
75 & 75 & 75 & 75 & IPA \\
50 & 50 & 50 & 50 & IPS \\
50 & 50 & 50 & 50 & IPS \\
25 & 25 & 25 & 25 & Bahasa \\
\hline
\end{tabular}

Tabel 3. Atribut penentuan rekomendasi jurusan berdasarkan nilai

$\begin{array}{r}\text { UN SMP } \\ \hline \text { Nilai UN } \\ \hline 127,5 \\ 122,5 \\ 147,5 \\ 145,0 \\ 102,5 \\ \hline\end{array}$

Tabel 4. Tipe data atribut yang digunakan

\begin{tabular}{lcccc}
\multirow{2}{*}{ Atribut } & \multicolumn{2}{c}{$\begin{array}{c}\text { Skenario Uji } \\
\text { Coba }\end{array}$} & Tipe Data & Keterangan \\
\cline { 2 - 3 } & $\mathbf{1}$ & $\mathbf{2}$ & & \\
\hline Nilai rapor, & 75 & & Integer & 75 (IPA), 50 \\
pilihan siswa, & 50 & & & (IPS), dan \\
pilihan orang & 25 & & & 25 (Bahasa) \\
tua, & & IPA & Polinomial & \\
rekomendasi & & IPS & & \\
guru BK, dan & & Bahasa & & \\
tes peminatan & & & Real & \\
Nilai UN & & & &
\end{tabular}

Tabel 5. Jumlah rekomendasi jurusan berdasarkan atributnya

\begin{tabular}{lccc}
\hline \multirow{2}{*}{\multicolumn{1}{c}{ Atribut }} & \multicolumn{3}{c}{ Jumlah } \\
\cline { 2 - 4 } & IPA & IPS & Bahasa \\
\hline Rapor & 52 & 53 & 184 \\
Siswa & 204 & 73 & 12 \\
Orang tua & 195 & 72 & 22 \\
Guru BK & 145 & 87 & 57 \\
Tes Peminatan & 28 & 26 & 235 \\
\hline
\end{tabular}

Skenario uji coba 1 dan skenario uji coba 2 ini juga akan diterapkan untuk atribut jurusan berdasarkan pilihan siswa itu sendiri, jurusan berdasarkan pilihan orang tua siswa, jurusan berdasarkan rekomendasi guru BK selama di SMP, dan jurusan berdasarkan hasil tes peminatan karena memiliki kasus yang sama, lebih jelas untuk ilustrasi data tersebut akan disajikan pada Tabel 2.

Sedangkan untuk nilai UN memiliki tipe numerik berupa tipe real karena bernilai desimal, karena nilainya heterogen. Ilustrasi nilai UN dapat dilihat pada Tabel 3. Lebih lengkap terkait tipe data untuk semua atribut disajikan pada Tabel 4. Jumlah rekomendasi jurusan berdasarkan semua atribut kecuali UN diperlihatkan pada Tabel 5. Sedangkan 
jumlah distribusi kelas ditunjukkan pada Gambar 2 yang memperlihatkan bahwa data pada penelitian ini memiliki karakteristik imbalanced class distribution (Márquez-Vera, et al., 2013), karena jumlah kelas tidak seimbang distribusinya (Li \& Sun, 2012), kelas Bahasa paling sedikit dibandingkan dengan jumlah kelas IPA dan IPS. Bahasa hanya sejumlah 32 dari 289 atau $0,11 \%$, IPA sejumlah 124 dari 289 atau $0,43 \%$, dan IPS sejumlah 133 dari 289 atau $0,46 \%$.

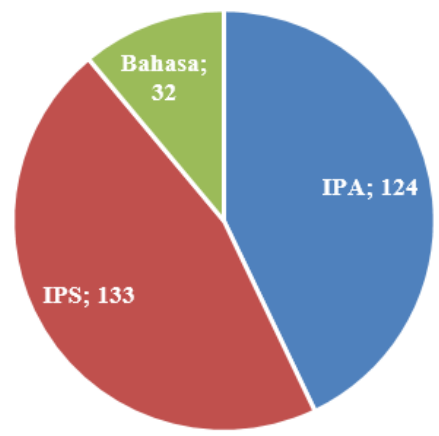

Gambar 2. Diagram imbalanced class distribution

Tahap kelima adalah validasi. Metode validasi yang digunakan pada penelitian ini seperti penelitian pada umumnya yang menggunakan 10-fold cross validation (Bavan, et al., 2019).

Sedangkan untuk tahapan keenam adalah evaluasi kinerja algoritma. Evaluasi kinerja algoritma klasifikasi hanya menggunakan (Tu, et al., 2009) yang didapat dari confusion matrix, karena ketiga evaluasi tersebut sudah dapat menggambarkan kinerja algoritma klasifikasi (Hussain, et al., 2019). Skenario uji coba dilakukan sebanyak 150 kali, di mana skenario uji coba berdasarkan tipe numerik dan polinomial masingmasing sebesar 75 kali. 4 algoritma, masing-masing algoritma dilakukan uji coba berdasarkan 3 sampling techniques yaitu linear sampling, shuffle sampling dan stratified sampling. Untuk C4.5 dan Random Forest masing-masing menggunakan 4 parameter criteria yang terdiri dari Gain Ratio, Information Gain, Gini Index dan Accuracy. Sedangkan untuk Deep Learning masing-masing random sampling digunakan 4 fungsi aktifasi yang terdiri dari Tanh, Rectifier, Maxout dan ExpRectifier. Terakhir masing-masing fungsi aktivasi dilakukan pengujian berdasarkan loss function yang terdiri dari Quadratic, CrossEntropy, Huber, dan Absolute. Semua skenario pengujian ini digunakan untuk melihat pengaruh masing-masing random dan parameter terhadap data pada penelitian ini. Software yang digunakan pada penelitian ini adalah Rapid Miner Studio 9.3.001.

Tahap ketuju adalah membandingkan hasil evaluasi masing-masing algoritma dari berbagai scenario uji coba, untuk mengetahui algoritma mana yang unggul dan yang lemah dalam permasalahan penelitian ini.

\section{HASIL DAN PEMBAHASAN}

Bagian ini akan menyajikan hasil uji coba yang telah dilakukan dalam penelitian ini dengan $150 \mathrm{kali}$ uji coba dengan membandingkan berbagai macam algoritma dan parameter masing-masing algoritma.

\section{1. $\mathrm{C} 4.5$}

Tabel 6. Hasil uji coba algoritma C4.5 dengan data bertipe integer

\begin{tabular}{|c|c|c|c|c|}
\hline $\begin{array}{l}\text { Random } \\
\text { Sampling }\end{array}$ & Creterion & $\begin{array}{c}\text { Accuracy } \\
(\%)\end{array}$ & $\begin{array}{l}\text { Weighted } \\
\text { Mean Recall } \\
(\%)\end{array}$ & $\begin{array}{c}\text { Weighted } \\
\text { Mean } \\
\text { Presisi } \\
(\%) \\
\end{array}$ \\
\hline \multirow[t]{4}{*}{ Linear } & Gain Ratio & 79,61 & 28,9 & 33,05 \\
\hline & $\begin{array}{l}\text { Information } \\
\text { Gain }\end{array}$ & 73,74 & 26,59 & 32,46 \\
\hline & Gini Index & 71,33 & 26,1 & 32,89 \\
\hline & Accuracy & 64,27 & 23,69 & 29,34 \\
\hline \multirow[t]{4}{*}{ Shuffled } & Gain Ratio & 92,04 & 88,85 & 88 \\
\hline & $\begin{array}{l}\text { Information } \\
\text { Gain }\end{array}$ & 86,54 & 85,07 & 86,64 \\
\hline & Gini Index & 89,64 & 87,05 & 87,99 \\
\hline & Accuracy & 78,52 & 76,58 & 78,2 \\
\hline \multirow[t]{4}{*}{ Stratified } & Gain Ratio & 89,64 & 85,83 & 86,7 \\
\hline & $\begin{array}{l}\text { Information } \\
\text { Gain }\end{array}$ & 84,79 & 79,84 & 84,32 \\
\hline & Gini Index & 89,63 & 85,79 & 89,55 \\
\hline & Accuracy & 77,84 & 77,19 & 79,21 \\
\hline
\end{tabular}

Tabel 7. Hasil uji coba algoritma C4.5 dengan data bertipe

\begin{tabular}{|c|c|c|c|c|}
\hline $\begin{array}{l}\text { Random } \\
\text { Sampling }\end{array}$ & Creterion & $\begin{array}{c}\text { Accuracy } \\
(\%)\end{array}$ & $\begin{array}{l}\text { Weighted } \\
\text { Mean Recall } \\
(\%)\end{array}$ & $\begin{array}{c}\text { Weighted } \\
\text { Mean } \\
\text { Presisi } \\
(\%)\end{array}$ \\
\hline \multirow[t]{4}{*}{ Linear } & Gain Ratio & 76,13 & 27,73 & 29,7 \\
\hline & $\begin{array}{l}\text { Information } \\
\text { Gain }\end{array}$ & 74,4 & 27,38 & 29,91 \\
\hline & Gini Index & 72,34 & 26,68 & 29,89 \\
\hline & Accuracy & 67,39 & 24,43 & 28,91 \\
\hline \multirow[t]{4}{*}{ Shuffled } & Gain Ratio & 91,37 & 90 & 87,26 \\
\hline & $\begin{array}{l}\text { Information } \\
\text { Gain }\end{array}$ & 86,88 & 84,06 & 84,57 \\
\hline & Gini Index & 87,57 & 88 & 84,74 \\
\hline & Accuracy & 74,74 & $\mathbf{7 4 , 7}$ & 75,66 \\
\hline \multirow[t]{4}{*}{ Stratified } & Gain Ratio & 88,26 & 85,91 & 84,6 \\
\hline & $\begin{array}{l}\text { Information } \\
\text { Gain }\end{array}$ & 87,23 & 83,15 & 83,53 \\
\hline & Gini Index & 85,84 & 83,55 & 83,29 \\
\hline & Accuracy & $\mathbf{7 5 , 0 7}$ & 74,22 & $\mathbf{7 5 , 0 5}$ \\
\hline
\end{tabular}

Berdasarkan hasil 24 kali uji coba pada algoritma C4.5 dengan menggunakan 4 criterion, baik data bertipe integer maupun bertipe polinomial, C4.5 memiliki kinerja terbaik ketika menggunakan shuffled sampling dengan criterion Gain ratio. Namun, C4.5 memiliki kinerja terburuk ketika menggunakan linear sampling dengan criterion accuracy. Sedangkan untuk perbandingan antara tipe data, tipe data integer memiliki kinerja bagus ketika menggunakan shuffled sampling, tetapi data bertipe integer juga memiliki kinerja terburuk ketika menggunakan linear sampling, seperti yang ditampilkan pada Tabel 6 dan Tabel 7.

\subsection{Gradient Boosting Trees}

Berdasarkan hasil 6 kali uji coba pada algoritma Gradient Boosting Trees dengan menggunakan distribution multinomial baik data bertipe integer maupun bertipe polinomial, Gradient Boosting Trees memiliki kinerja sama dengan C4.5, terbaik ketika menggunakan shuffled sampling. Namun, Gradient Boosting Trees memiliki kinerja terburuk ketika menggunakan linear sampling. Sedangkan untuk perbandingan antara tipe data, 
Gradient Boosting Trees memiliki kinerja berbeda dengan $\mathrm{C} 4.5$ tipe data integer memiliki kinerja bagus ketika menggunakan shuffled sampling, tetapi data bertipe polinomial memiliki kinerja terburuk ketika menggunakan linear sampling, seperti yang ditampilkan pada Tabel 8 dan Tabel 9.

Tabel 8. Hasil uji coba algoritma Gradient Boosting Trees dengan

\begin{tabular}{cccc}
\multicolumn{4}{c}{ data bertipe integer } \\
\hline $\begin{array}{c}\text { Random } \\
\text { Sampling }\end{array}$ & $\begin{array}{c}\text { Accuracy } \\
(\%)\end{array}$ & $\begin{array}{c}\text { Weighted } \\
\text { Mean Recall } \\
(\%)\end{array}$ & $\begin{array}{c}\text { Weighted } \\
\text { Mean Presisi } \\
(\%)\end{array}$ \\
\hline Linear & $\mathbf{7 4 , 8 2}$ & $\mathbf{2 6 , 9 3}$ & $\mathbf{2 8 , 9 4}$ \\
Shuffled & $\mathbf{9 1 , 7 1}$ & $\mathbf{9 1 , 6}$ & $\mathbf{8 9 , 7 5}$ \\
Stratified & 89,99 & 89,47 & 88,15 \\
\hline
\end{tabular}

Tabel 9. Hasil uji coba algoritma Gradient Boosting Trees dengan

\begin{tabular}{cccc}
\multicolumn{4}{c}{ data bertipe polinomial } \\
\hline Random & $\begin{array}{c}\text { Accuracy } \\
(\%)\end{array}$ & $\begin{array}{c}\text { Weighted } \\
\text { Mean Recall } \\
(\%)\end{array}$ & $\begin{array}{c}\text { Weighted } \\
\text { Mean Presisi } \\
(\%)\end{array}$ \\
\hline Linear & $\mathbf{7 3 , 4 4}$ & $\mathbf{2 6 , 4 7}$ & $\mathbf{2 8 , 9 4}$ \\
Shuffled & $\mathbf{9 1 , 3 5}$ & $\mathbf{9 1 , 3 2}$ & $\mathbf{8 9 , 5 4}$ \\
Stratified & 89,99 & 89,47 & 88,15 \\
\hline
\end{tabular}

\subsection{Random Forest}

Tabel 10. Hasil uji coba algoritma Random Forest dengan data

\begin{tabular}{|c|c|c|c|c|}
\hline $\begin{array}{l}\text { Random } \\
\text { Sampling }\end{array}$ & Creterion & $\begin{array}{c}\text { Accuracy } \\
(\%)\end{array}$ & $\begin{array}{c}\text { Weighted } \\
\text { Mean Recall } \\
(\%)\end{array}$ & $\begin{array}{c}\text { Weighted } \\
\text { Mean } \\
\text { Presisi } \\
(\%) \\
\end{array}$ \\
\hline \multirow[t]{4}{*}{ Linear } & Gain Ratio & 81,7 & 29,6 & 33,05 \\
\hline & $\begin{array}{l}\text { Information } \\
\text { Gain }\end{array}$ & 81,01 & 29,55 & 33,05 \\
\hline & Gini Index & 81,35 & 29,45 & 32,91 \\
\hline & Accuracy & 71,45 & 26,14 & 29,37 \\
\hline \multirow[t]{4}{*}{ Shuffled } & Gain Ratio & 92,44 & 92,56 & 92,33 \\
\hline & $\begin{array}{l}\text { Information } \\
\text { Gain }\end{array}$ & 93,78 & 92,64 & 92,89 \\
\hline & Gini Index & 93,44 & 92,44 & 92,66 \\
\hline & Accuracy & 84,06 & 81,35 & 84,34 \\
\hline \multirow[t]{4}{*}{ Stratified } & Gain Ratio & 92,76 & 91,52 & 90,07 \\
\hline & $\begin{array}{l}\text { Information } \\
\text { Gain }\end{array}$ & 92,75 & 91,54 & 91,88 \\
\hline & Gini Index & 92,4 & 89,55 & 91,66 \\
\hline & Accuracy & 82 & 74,17 & 81,68 \\
\hline
\end{tabular}

Tabel 11. Hasil uji coba algoritma Random Forest dengan data bertipe polinomial

\begin{tabular}{|c|c|c|c|c|}
\hline $\begin{array}{l}\text { Random } \\
\text { Sampling }\end{array}$ & Creterion & $\begin{array}{c}\text { Accuracy } \\
(\%)\end{array}$ & $\begin{array}{l}\text { Weighted } \\
\text { Mean Recall } \\
(\%)\end{array}$ & $\begin{array}{c}\text { Weighted } \\
\text { Mean } \\
\text { Presisi } \\
(\%) \\
\end{array}$ \\
\hline \multirow[t]{4}{*}{ Linear } & Gain Ratio & 80,31 & 31,28 & 34,23 \\
\hline & $\begin{array}{l}\text { Information } \\
\text { Gain }\end{array}$ & 81,03 & 29,6 & 33,35 \\
\hline & Gini Index & 79,99 & 29,27 & 33,38 \\
\hline & Accuracy & 81,03 & 29,66 & 33,5 \\
\hline \multirow[t]{4}{*}{ Shuffled } & Gain Ratio & 93,09 & 94,36 & 89,79 \\
\hline & $\begin{array}{l}\text { Information } \\
\text { Gain }\end{array}$ & 94,13 & 95,14 & 92,95 \\
\hline & Gini Index & 93,09 & 94,27 & 90,08 \\
\hline & Accuracy & 93,09 & 94,44 & 90,59 \\
\hline \multirow[t]{4}{*}{ Stratified } & Gain Ratio & 92,75 & 92,06 & 89,63 \\
\hline & $\begin{array}{l}\text { Information } \\
\text { Gain }\end{array}$ & 93,44 & 93,42 & 91,07 \\
\hline & Gini Index & 92,06 & 92,42 & 90,19 \\
\hline & Accuracy & 92,4 & 92,67 & 90,37 \\
\hline
\end{tabular}

Berdasarkan hasil 24 kali uji coba pada algoritma Random Forest dengan menggunakan 4 criterion, baik data bertipe integer maupun bertipe polinomial, Random Forest memiliki kinerja sama seperti C4.5 dan Gradient Boosting Trees terbaik ketika menggunakan shuffled sampling dengan criterion Gain ratio. Namun, Random Forest memiliki kinerja terburuk ketika menggunakan linear sampling dengan criterion accuracy. Sedangkan untuk perbandingan antara tipe data, tipe data polinomial Random Forest memiliki kinerja berbeda baik dengan $\mathrm{C} 4.5$ maupun Gradient Boosting Trees, di mana Random Forest bagus ketika menggunakan shuffled sampling, tetapi ketika data bertipe integer kinerja Random Forest menjadi buruk ketika menggunakan linear sampling, berbanding terbalik dengan Gradient Boosting Trees, seperti yang ditampilkan pada Tabel 10 dan Tabel 11

\subsection{Deep Learning}

Tabel 12. Hasil uji coba algoritma Deep Learning dengan data bertipe integer

\begin{tabular}{|c|c|c|c|c|c|}
\hline $\begin{array}{l}\text { Random } \\
\text { Sampling }\end{array}$ & Activation & Loss Fuction & $\begin{array}{c}\text { Accuracy } \\
(\%)\end{array}$ & $\begin{array}{c}\text { Weighted } \\
\text { Mean } \\
\text { Recall }(\%)\end{array}$ & $\begin{array}{c}\text { Weighted } \\
\text { Mean } \\
\text { Presisi }(\%)\end{array}$ \\
\hline \multirow{16}{*}{ Linear } & \multirow[t]{4}{*}{ Tanh } & Quadratic & 77,24 & 30,73 & 32,6 \\
\hline & & CrossEntropy & 78,28 & 31,09 & 32,67 \\
\hline & & & & 30,47 & 32,5 \\
\hline & & Absolute & 80,69 & 28,98 & 31,45 \\
\hline & \multirow{4}{*}{ Rectifier } & Quadratic & 80,69 & 31,66 & 32,88 \\
\hline & & CrossEntropy & 85,52 & 33,59 & 33,83 \\
\hline & & Huber & 81,02 & 31,47 & 32,23 \\
\hline & & Absolute & 57,25 & 24,01 & 29,09 \\
\hline & \multirow[t]{4}{*}{ Maxout } & Quadratic & 79,98 & 32,98 & 32,95 \\
\hline & & CrossEntropy & 79,3 & 32,56 & 32,39 \\
\hline & & Huber & 82,06 & 32,32 & 32,55 \\
\hline & & Absolute & 77,93 & 32,5 & 30,76 \\
\hline & \multirow[t]{4}{*}{ ExpRectifier } & Quadratic & 78,28 & 30,76 & 32,17 \\
\hline & & CrossEntropy & 80,69 & 31,97 & 33,5 \\
\hline & & Huber & 79,31 & 31,47 & 32,94 \\
\hline & & Absolute & 80 & 31,66 & 32,67 \\
\hline \multirow[t]{16}{*}{ Shuffled } & \multirow[t]{4}{*}{ Tanh } & Quadratic & 92,69 & 93,21 & 93,86 \\
\hline & & CrossEntropy & 91,7 & 93,26 & 93,78 \\
\hline & & Huber & 91,69 & 93,71 & 94,21 \\
\hline & & Absolute & 83,71 & 75,37 & 78,37 \\
\hline & \multirow[t]{4}{*}{ Rectifier } & Quadratic & 92,72 & 89,39 & 93,83 \\
\hline & & CrossEntropy & $\mathbf{9 3 , 4 5}$ & 91,2 & 94,26 \\
\hline & & Huber & 91,71 & 88,71 & 92,81 \\
\hline & & Absolute & 86,49 & 76,35 & 78,41 \\
\hline & \multirow[t]{4}{*}{ Maxout } & Quadratic & $\mathbf{9 3 , 4 5}$ & 92,63 & 94,27 \\
\hline & & CrossEntropy & 92,41 & 90,01 & 93,22 \\
\hline & & Huber & 89,98 & 88,55 & 87,67 \\
\hline & & Absolute & 87,86 & 75,92 & 75,15 \\
\hline & \multirow{4}{*}{ ExpRectifier } & Quadratic & 92,38 & 93,61 & 94,3 \\
\hline & & CrossEntropy & 93,08 & 94,61 & 94,52 \\
\hline & & Huber & 91,33 & 90,71 & 93,59 \\
\hline & & Absolute & 79,56 & 66,47 & 68,51 \\
\hline \multirow[t]{16}{*}{ Stratified } & \multirow[t]{4}{*}{ Tanh } & Quadratic & 90,64 & 92,06 & 92,57 \\
\hline & & CrossEntropy & 90,99 & 92,58 & 93,06 \\
\hline & & Huber & 91,33 & 92,81 & 94,09 \\
\hline & & Absolute & 86,83 & 76,72 & 83,01 \\
\hline & \multirow{4}{*}{ Rectifier } & Quadratic & 93,42 & 91,6 & 94,65 \\
\hline & & CrossEntropy & 94,14 & 92,43 & 95,05 \\
\hline & & Huber & 93,08 & 91,64 & 93,65 \\
\hline & & Absolute & 90 & 76,75 & 80,86 \\
\hline & \multirow[t]{4}{*}{ Maxout } & Quadratic & 90,97 & 88,09 & 91,43 \\
\hline & & CrossEntropy & 90,3 & 86,5 & 89,2 \\
\hline & & Huber & 89,27 & 86,51 & 86,22 \\
\hline & & Absolute & 89,3 & 77,13 & 82,66 \\
\hline & \multirow[t]{4}{*}{ ExpRectifier } & Quadratic & 90,64 & 92,04 & 91,88 \\
\hline & & CrossEntropy & 90,99 & 91,74 & 93,25 \\
\hline & & Huber & 90,99 & 93,11 & 93,43 \\
\hline & & Absolute & 83,04 & 72,41 & 80,94 \\
\hline
\end{tabular}

Berdasarkan hasil 48 kali uji coba pada algoritma Deep Learning dengan menggunakan distribution multinomial baik data bertipe integer maupun bertipe polinomial, Deep Learning memiliki kinerja sama dengan terbaik ketika menggunakan Stratified sampling, dan loss function CrossEntropy. Namun, Deep Learning memiliki kinerja terburuk ketika menggunakan linear sampling dan loss function absolute. Sedangkan untuk perbandingan antara tipe data, Deep Learning memiliki kinerja terbaik pada tipe data integer dengan menggunakan activation Rectifier, tetapi data bertipe polinomial memiliki kinerja terburuk ketika menggunakan Tanh, seperti yang ditampilkan pada Tabel 12 dan Tabel 13. Mayoritas penggunaan loss function untuk data penelitian ini bagus ketika menggunakan CrossEntropy dan jelek ketika menggunakan 
absolute. Untuk kinerja penggunaan atribut berupa polinomial memiliki kinerja lebih baik ketika menggunakan stratified random, activation Tahn, dan loss function CrossEntropy, tetapi tipe polinomial juga memilik kinerja jelek ketika menggunakan linear sampling, activation Maxout, dan loss function absolute dibandingkan dengan bertipe interger tetapi juga memiliki kinerja terburuk, kebalikan dengan C4.5.

Tabel 13. Hasil uji coba algoritma Deep Learning dengan data bertipe polinomial

\begin{tabular}{|c|c|c|c|c|c|}
\hline $\begin{array}{l}\text { Random } \\
\text { Sampling }\end{array}$ & Activation & Loss Fuction & $\begin{array}{c}\text { Accuracy } \\
(\%)\end{array}$ & $\begin{array}{c}\text { Weighted } \\
\text { Mean } \\
\text { Recall }(\%)\end{array}$ & $\begin{array}{c}\text { Weighted } \\
\text { Mean } \\
\text { Presisi }(\%)\end{array}$ \\
\hline \multirow[t]{16}{*}{ Linear } & \multirow[t]{4}{*}{ Tanh } & Quadratic & 79,66 & 32,81 & 32,84 \\
\hline & & CrossEntropy & 80,69 & 33,18 & 32,88 \\
\hline & & Huber & 79,3 & 32,7 & 32,86 \\
\hline & & Absolute & 80,33 & 33,19 & 33,79 \\
\hline & \multirow[t]{4}{*}{ Rectifier } & Quadratic & 74,14 & 29,03 & 32,98 \\
\hline & & CrossEntropy & 76,21 & 30,06 & 36,48 \\
\hline & & Huber & 70,34 & 27,45 & 29,54 \\
\hline & & Absolute & 80,34 & 28,12 & 31,67 \\
\hline & \multirow{4}{*}{ Maxout } & Quadratic & 71,38 & 28,64 & 32,27 \\
\hline & & CrossEntropy & 77,24 & 29,79 & 32,94 \\
\hline & & Huber & 70,34 & 27,42 & 29,5 \\
\hline & & Absolute & 44,84 & 17,37 & 22,03 \\
\hline & \multirow[t]{4}{*}{ ExpRectifier } & Quadratic & 79,66 & 32,85 & 33,08 \\
\hline & & CrossEntropy & 80,34 & 33,09 & 32,92 \\
\hline & & Huber & 80 & 33,01 & 33,38 \\
\hline & & Absolute & 87,93 & 32,86 & 32,08 \\
\hline \multirow[t]{16}{*}{ Shuffled } & \multirow[t]{4}{*}{ Tanh } & Quadratic & 91,7 & 92,22 & 87,84 \\
\hline & & CrossEntropy & 93,42 & 94,11 & 90,01 \\
\hline & & Huber & 93,42 & 94,94 & 89,96 \\
\hline & & Absolute & 86,12 & 65,88 & 61,59 \\
\hline & \multirow[t]{4}{*}{ Rectifier } & Quadratic & 88,57 & 90,8 & 86,42 \\
\hline & & CrossEntropy & 90,31 & 91,76 & 87,9 \\
\hline & & Huber & 84,42 & 83,71 & 80,21 \\
\hline & & Absolute & 80,6 & 72,1 & 68,46 \\
\hline & \multirow{4}{*}{ Maxout } & Quadratic & 87,19 & 87,94 & 85,22 \\
\hline & & CrossEntropy & 86,86 & 87,4 & 85,06 \\
\hline & & Huber & 88,58 & 90,39 & 86,69 \\
\hline & & Absolute & 71,65 & 62,37 & 56,89 \\
\hline & \multirow[t]{4}{*}{ ExpRectifier } & Quadratic & 92,75 & $\mathbf{9 4 , 5 4}$ & 89,52 \\
\hline & & CrossEntropy & 93,78 & 93,88 & 90,04 \\
\hline & & Huber & 93,08 & 93,77 & 89,82 \\
\hline & & Absolute & 87,87 & 65,85 & 59,66 \\
\hline \multirow[t]{16}{*}{ Stratified } & \multirow[t]{4}{*}{ Tanh } & Quadratic & 92,38 & 94,28 & 89,56 \\
\hline & & CrossEntropy & 94,82 & $\mathbf{9 6 , 0 8}$ & 92,43 \\
\hline & & $\begin{array}{l}\text { Huber } \\
\text {. }\end{array}$ & 92,03 & 94,05 & 88,88 \\
\hline & & Absolute & 88,24 & 73,03 & 66,81 \\
\hline & \multirow[t]{4}{*}{ Rectifier } & Quadratic & 86,13 & 88,92 & 85,51 \\
\hline & & CrossEntropy & 88,9 & 90,15 & 89,16 \\
\hline & & Huber & 87,17 & 89,44 & 85,58 \\
\hline & & Absolute & 66,38 & 52,3 & 46,08 \\
\hline & \multirow[t]{4}{*}{ Maxout } & Quadratic & 86,49 & 87,48 & 86,92 \\
\hline & & CrossEntropy & 87,17 & 89,1 & 87 \\
\hline & & Huber & 86,15 & 88,91 & 86,81 \\
\hline & & Absolute & 73,34 & 62,46 & 57,98 \\
\hline & \multirow{4}{*}{ ExpRectifier } & Quadratic & 92,72 & $\mathbf{9 4 , 5 8}$ & 89,18 \\
\hline & & CrossEntropy & 93,07 & 92,77 & 90,7 \\
\hline & & Huber & 91 & 92,42 & 87,25 \\
\hline & & Absolute & 85,46 & 64,17 & 57,99 \\
\hline
\end{tabular}

Tabel 14. Perbandingan algoritma dengan data bertipe integer

\begin{tabular}{ccccc}
\hline Algoritma & Bagus-Buruk & $\begin{array}{c}\text { Accuracy } \\
(\%)\end{array}$ & $\begin{array}{c}\text { Weighted Mean } \\
\text { Recall } \\
\mathbf{\%})\end{array}$ & $\begin{array}{c}\text { Weighted } \\
\text { Mean } \\
\text { Presisi } \\
(\boldsymbol{\%})\end{array}$ \\
\hline C4.5 & Linear & 64,27 & $\mathbf{2 3 , 6 9}$ & 29,34 \\
$\begin{array}{c}\text { Gradient } \\
\text { Boosting } \\
\text { Trees }\end{array}$ & Shuffled & 92,04 & 88,85 & 88 \\
Random & Linear & 74,82 & 26,93 & $\mathbf{2 8 , 9 4}$ \\
Forest & Shuffled & 91,71 & 91,6 & 89,75 \\
Deep & Linear & 71,45 & 26,14 & 29,37 \\
Learning & Shuffled & 94,13 & $\mathbf{9 5 , 1 4}$ & 92,95 \\
& Linear & $\mathbf{5 7 , 2 5}$ & 24,01 & 29,09 \\
& Stratified & $\mathbf{9 4 , 1 4}$ & 92,43 & $\mathbf{9 5 , 0 5}$ \\
\hline
\end{tabular}

Berdasarkan semua uji coba didapatkan kesimpulan bahwa algoritma yang bagus untuk karakteristik data pada penelitian ini adalah algoritma Deep Learning dengan menggunakan stratified sampling disusul algoritma Random Forest. Namun, Deep learning bisa memiliki kinerja terburuk jika menggunakan linear sampling seperti yang disajikan pada Tabel 14. Ketiga algoritma kecuali Deep Learning sama-sama memiliki performa bagus jika menggunakan shuffled sampling dikarena ketiga algoritma tersebut berbasis tree. Sedangkan semua linear sampling menghasilkan kinerja terburuk apapun algoritma dan parameternya, karena linear sampling menghasilkan imbalanced class distribution antara data latih dengan data uji, berbeda dengan shuffled sampling dan stratified sampling yang cenderung balanced class distribution antara data latih dengan data uji.

\section{KESIMPULAN DAN SARAN}

Penelitian ini menghasilkan kesimpulan bahwa algoritma yang unggu adalah Deep Learning disusul oleh Random Forest dengan syarat menggunakan stratified sampling, tetapi Deep Learning juga bisa menghasilkan nilai terburuk dari pada algoritma lainnya jika menggunakan Linear Sampling. Mayoritas linear sampling menghasilkan kinerja terburuk. Sedangkan shuffled sampling memiliki kinerja bagus untuk algoritma berbasis tree, sedangkan stratified sampling cocok untuk algoritma Deep Learning.

Penerapan cretarion Gain Ratio pada C4.5 dan Random Forest memiliki kinerja bagus, berbading terbalik ketika menggunakan cretarion accuracy. Penerapan loss function CrossEntropy pada Deep Learning mayoritas memberikan hasil terbaik, sedangkan ketika menggunakan loss function memiliki hasil buruk. Kinerja bagus didasarkan pada hasil evaluasi accuracy, weighted mean precision, dan weighted mean recall. Shuffled sampling dan stratified sampling menggambarkan distribusi antar kelas seimbang baik pada data latih maupun data uji, begitu sebaliknya dengan Linear Sampling .

Penerapan data bertipe integer cocok untuk algoritma C4.5 sedangkan untuk Gradient Boosting Trees, Random Forest, dan Deep Learning cocok untuk tipe data polinomial asal tidak menggunakan linear sampling.

Berdasarkan hasil penelitian ini, hipotesa awal adalah benar, bahwa C4.5 lebih buruk kinerjanya dibandingkan ketiga algoritma lainnya. Ilustrasi terkait penjelasan ini dapat dilihat pada Tabel 14.

Penelitian selanjutnya diharapkan dapat menganalisis secara mendalam mengapa parameterparameter tersebut bisa memberikan nilai bagus atau buruk.

\section{UCAPAN TERIMA KASIH}

Penghargaan dan terima kasih kepada Direktorat Riset dan Pengabdian Masyarakat, Dirjen Penguatan Riset dan Pengembangan, Kementerian Riset, Teknologi dan Pendidikan Tinggi, yang telah membiayai penelitian Kerjasama Antar Perguruan Tinggi 2019 dengan judul Educational Data Mining Berbasis Klasifikasi untuk Menganalisis Mahasiswa Berpotensi Berhenti Kuliah pada Kasus Imbalanced Class Distribution. 


\section{DAFTAR PUSTAKA}

BAVAN, L. et al., 2019. Adherence monitoring of rehabilitation exercise with inertial sensors: A clinical validation study. Gait \& Posture, 70(May), pp. 211-217.

BROWN, I. \& MUES, C., 2012. An experimental comparison of classification algorithms for imbalanced credit. Expert Systems with Applications, 39(2012), p. Expert Systems with Applications.

HANDHAYANI, T., HENDRYLI, J. \& HIRYANTO, L., 2018. Comparison of Shallow and Deep Learning Models for Classification of Lasem Batik Patterns. Semarang, IEEE.

HUSSAIN, R. G. et al., 2019. A performance comparison of machine learning classification approaches for robust activity of daily living recognition. Artificial Intelligence Review, 52(1), p. 357-379.

KHAN, A. \& GHOSH, S. K., 2018. Data mining based analysis to explore the effect of teaching on student performance. Education and Information Technologies, 23(4), $\mathrm{p}$. 1677-1697.

KRISTANTO, O., 2014. Penerapan algoritma klasifikasi data mining ID3 untuk menentukan penjurusan siswa SMAN 6 Semarang, Semarang: Universitas Dian Nuswantoro.

KUSTIYAHNINGSIH, Y. \& SYAFA'AH, N., 2015. Sistem pendukung keputusan untuk menentukan jurusan pada siswa sma menggunakan metode kNN dan SMART. Jurnal Sistem Informasi Indonesia, 1(1), pp. 19-28.

LI, H. \& SUN, J., 2012. Forecasting business failure: The use of nearest-neighbour support vectors and correcting imbalanced samples-Evidence from the Chinese hotel industry. Tourism Management, 33(3), pp. 622-634.

MÁRQUEZ- VERA, C. et al., 2016. Early dropout prediction using data mining: a case study with high school students. Expert Systems, 33(1), pp. 107-124.

MÁRQUEZ-VERA, C., CANO, A., ROMERO, C. \& VENTURA, S., 2013. Predicting student failure at school using genetic programming and different data mining approaches with high dimensional and imbalanced data. Applied Intelligence, 38(3), p. 315-330.

MUTROFIN, S. et al., 2019. Detection of Potentially Students Drop Out of College in Case of Missing Value Using C4.5. Bandung, IEEE.

NATEK, S. \& ZWILLING, M., 2014. Student data mining solution-knowledge management system related to higher education institutions. Expert Systems with Applications, 41(14), pp. 6400-6407.

PEÑA-AYALA, A., 2014. Educational data mining: A survey and a data mining-based analysis of recent works. Expert Systems with Applications, 41(4), pp. 1432-1462.

SWASTINA, L., 2013. Penerapan Algoritma C4.5 Untuk Penentuan Jurusan Mahasiswa. Gema Aktualita, 2(1), pp. 93-98.

TU, M. C., SHIN, D. \& SHIN, D., 2009. Effective Diagnosis of Heart Disease through Bagging Approach. Tianjin, China, IEEE. 
Halaman ini sengaja dikosongkan 